Gusmaniarti $^{1}$ Wardah Suweleh ${ }^{2}$

\section{Analisis Perilaku Home Service Orang Tua terhadap Perkembangan Kemandirian dan Tanggung Jawab Anak}

\begin{abstract}
Abstrak
Penelitian ini memfokuskan pada analisa perilaku orang tua terhadap anak dengan menggunakan metode problem-based di sebuah Lembaga TK Insan cendekia Grabagan tulangan. Perilaku home service yang berlebihan di lakukan orang tua sangat mempengaruhi perkembangan perilaku mandiri dan tanggungjawab anak.yang terlihat jelas di lingkungan sekolah. Tahapan pengamatan yang lakukan peneliti melibatkan pengembangan materi, validasi ahli dan pengujian lapangan berbasis karakter anak. Metode pengumpulan data menggunakan observasi, wawancara, dokumentasi dan kuesioner. Hasil penelitian menggambarkan bahwa dari 50 siswa paud yang ber umur 5 sampai 6 tahun $80 \%$ persen kegiatan kesiapan berangkat sekolah di layani oleh orang tua, $90 \%$ kegiatan merapikan kamar secara sederhana di lakukan orang tua, $60 \%$ aktifitas merapikan permainan di rumah dilakukan orang tua. Data analisis di lakukan secara kualitatif deskriptif.
\end{abstract}

Kata kunci: perilaku home service, orang tua, mandiri dan tanggungjawab anak

\begin{abstract}
This study focuses on analyzing the behavior of parents towards children by using problem-based methods in a Rehabilitation Institution of TK Scholars. Excessive home service behavior by parents greatly influences the development of independent behavior and children's responsibility which is clearly visible in the school environment. The stages of observation conducted by researchers involve the development of material, expert validation and character-based field testing of children. Methods of collecting data using observation, interviews, documentation and questionnaires. The results of the study illustrate that from 50 paud students aged 5 to 6 years $80 \%$ percent of readiness to go to school are served by parents, $90 \%$ of simple tidy up activities are done by parents, $60 \%$ of activities tidying up at home are done by parents . Data analysis was carried out qualitatively descriptive.
\end{abstract}

Keywords: home service behavior, parents, independent and child responsibility

\footnotetext{
${ }^{1}$ Prodi S1 PAUD FKIP, Universitas Muhammadiyah Surabaya, Email : gusmaniarti01@gmail.com

${ }^{2}$ Prodi S1 PAUD FKIP, Universitas Muhammadiyah Surabaya
} 


\section{PENDAHULUAN}

Bagian ini berisi tentang latar belakang penelitian, permasalahan penelitian atau tujuan penelitian dan state of the Art Penelitian (Penulisan Bagian pendahuluan hingga Kesimpulan, Times New romans, font 12, spasi 1,15)

Makhluk kecil yang lucu selalu menggemaskan dan di idamkan oleh seluruh pasangan suami istri di seluruh antero dunia adalah anak. Anak adalah anugerah terindah yang dititipkan Tuhan YME kapada para orang tua, dimana mereka mengharap diberi kasih sayang, dirawat, di belai, di arahkan, di contohkan dan dididik dengan baik. Anak merupakan penyemangat para orang tua untuk bekerja mencari nafkah dan kebutuhan keluarganya, apapun akan dilakukan para orang tua demi buah hati tercinta. Haditono mengungkapkan dalam damayanti,1992, Anak adalah makhluk kecil yang membutuhkan pemeliharaan, perhatian, kasih sayang serta tempat bagi perkembangannya. Anak-anak milenial jaman sekarang jauh berbeda dengan anak-anak tahun 70 dan 80an. Kemajuan tekhnologi membuat peradaban manusia berubah, kultur anak maupun orang tua juga jauh lebih maju dan komplek, Anak-anak tahun 70 dan 80an mereka bermain bersama dengan alat permainan yang terbatas namun kebersamaan dengan teman sebaya sangat lah kuat, disisi lain orang tua cendrung berada di rumah, Seandaikan ada orang tua bekerja tidak menghabiskan waktu di luar Anak-anak milenia jaman sekarang cerdrung bermain dengan alat teknologi yang ada di sekitar rumah tanpa perlu ia mencari teman untuk bermain. Kecendrungan orang tua mereka banyak bekerja dengan rutinitas waktu yang tetap dr jam 08.00 sampai pukul 17.00 dan berada di rumah sudah pukul 20.00, keberadaan rumah cendrung hanya sesaat dan hanya di jadikan tempat istirahat.

Orang Tua merupakan dua orang malaikat yang ada di muka bumi dalam menjaga anak-anak dan keluarganya, mereka yang menjadikan kehidupan dalam keluarga seperti surga dunia namun di tangan mereka juga kehidupan keluarga bisa seperti neraka dunia. Orang tua merupakan Roll Model bagi kehidupan anaknya. Anak akan mencontoh apa yang dilihat, di ajarkan dan di biasakan orangtuanya dan akan membekas dalam kehidupannya. Rutinitas orang tua yang padat cendrung memperkerjakan asisten rumah tangga untuk membantu mengerjakan pekerjaan rumah serta mengasuh anak-anaknya. Kelelahan aktifitas orang tua sering sekali tidak mau di repotkan dengan menamakan sifat mandiri seperti apabila anak mau minum, orang tua langsung mengambilkan gelas, air dan memberikan kepada anak padahal prilaku mengambil air minum dapat dilakukan anak sendiri. Asisten rumah tanggapun karena takut dengan majikan maka seluruh kebutuhan anak di bantu 100\% tanpa anak harus menyelesaikan problem yang dia hadapi . "HOME SERVICE" dapat di artikan layanan rumah, atau prilaku orang dewasa dalam melayani, membimbing dan melayani anak di rumah, Menurut pendapat Euis( 2004:18 ) layanan orang tua di rumah merupakan rangkaian interaksi yang dilakukan setiap saat supaya anak memiliki kecakapan hidup. Dua suku kata "Home Service" tidak mengandung arti dan pengertian yang salah, namun bagaimana apa bila prilaku home service ini di berikan secara berlebihan pastinya akan berdampak negatif terhadap perkembangan, serta karakter anak itu sendiri. Panduan mendidik anak menurut Sahabat Nabi Ali Bin ABi Thalib RA dalam riwayatnya : "Ajaklah anak bermain pada tujuh tahun pertama, disiplinkanlah anak pada tujuh tahun kedua dan bersahabatlah pada anak usia tujuh tahun ketiga." Tergambar bahwa anak umur 7 tahun ke bawah memang dididik sambil bermain. Sedang anak usia 7 s/d 14 tahun mulailah mendisiplinkannya . Lembaga TK Insan Cendekia didirikan pada tahun 2008 yang berada di Perum TAS 3 Daerah Grabagan Tulangan Sidoarjo, dalam proses pembelajaran perkembangan sosial emosional anak selalu mendapat perhatian oleh kepala sekolah dan para guru disekolah 
. Pada proses pembelajaran tahun ini ada beberapa gambaran anak usia 5-6 tahun di instruksikan guru untuk merapikan mainan setelah bermain dari 43 siswa hanya 10 siswa yang bersemangat merapikan alat permainan tersebut sedang 33 siswa kecendrungan nya tidak bersemangat. Jadwal kedatangan siswa pun menjadi permasalahan. Berkaitan dengan hal tersebut perlu kiranya dicari bukti secara empirik dengan melakukan sebuah observasi dan wawancara pihak sekolah dengan orang tua di rumah

Menelaah latar belakang yang terjadi di TK Insan Cendekia maka peneliti perlu menganalisis perilaku home service orang tua terhadap perkembangan kemandirian dan tanggungjawab anak usia 5 - 6 di TK Insan Cendekia

Anak merupakan sosok individu yang unik dan memiliki karakteristik khusus, baik dari segi kognitif, sosial, emosi, bahasa, fisik maupun motorik yang sedang mengalami proses perkembangan sangat pesat (Masitoh:2013). Karakteristik yang unik yang dimiliki seorang anak membuat kebahagiaan tersendiri orang-orang di sekitar mereka. mereka selalu aktif, dinamis, antusias dan ingin tahu terhadap apa yang dilihat, didengar, dirasakan, mereka seolah-olah tak pernah berhenti bereksplorasi dan belajar. Menurut Haditono (dalam Damayanti, 1992) anak adalah makhluk yang membutuhkan pemeliharaan, kasih sayang dan tempat bagi perkembangannya. Anak merupakan dambaan dan harapan setiap ayah bunda, mereka adalah hasil cinta kasih kedua orang tuanya. Buah hati, pelipur lara, pelengkap keceriaan rumah tangga, investasi masa depan, investasi pelindung orang tua ketika mereka telah lanjut usia. dalam QS Al Furqaan 25 : 74 Artinya : "Ya Tuhan kami, anugerahkanlah kepada kami isteri-isteri kami dan keturunan kami sebagai penyenang hati (kami), dan jadikanlah kami imam bagi orang-orang yang bertakwa". Kedudukan tertinggi seorang anak menjadi penyejuk hati kedua orang tua nya.

Orang tua merupakan ayah dan ibu kandung, yang telah melahirkan dan membesarkan anak-anak nya. Orang tua merupakan pendidik utama dan pertama bagi anak-anak mereka, karena dari merekalah anak menerima pendidikan. Dengan demikian bentuk pertama dari pendidikan terdapat dalam keluarga. Pada umumnya pendidikan dalam rumah tangga itu bukan berpangkal tolak dari kesadaran,dan pengertian yang lahir dari pengetahuan mendidik. Namun dari sebuah pengalaman yang di alami orang tua. Mereka yang memberikan kita arti kehidupan. Selain itu orang tua yang menyayangi kita tanpa ada perbedaan. Menurut Singgih D.Gunarsa (1976: 27) mengatakan bahwa orangtua adalah dua individu yang berbeda mereka memasuki hidup bersama dengan membawa pandangan, pendapat dan kebiasaan sehari-hari yang akan di tularkan kepada anak keturunannya. Sementara Zakiyah Darajat (1996: 4) merumuskan bahwa orangtua sebagai pembentuk pribadi pertama dalam kehidupan anak. Bisa di katakan sesosok pendidik yang handal.

\section{Kemandirian dan Tanggungjawab anak}

Kemandirian dapat diartikan Menurut Bacharuddin Mustafa (2008: 75) adalah kemampuan untuk mengambil sebuah pilihan dan menerima konsekwensi yang menyertainya. Kemandirian pada anak-anak terlihat ketika mereka menggunakan pola pikir sendiri dalam mengambil sebuah keputusan; dari mencari aktifitas apa yang diinginkan sampai hasil yang didapat, atau memilih alat belajar yang ingin digunakannya, memilih teman bermain, sampai hal-hal yang relatif lebih rumit dan menyertakan konsekwensi-konsekwensi tertentu yang lebih serius.Perilaku sosial yang berkembang pada awal anak usia dini diawali oleh perilaku dalam keluarga dan hubungan sosial dengan teman sebaya serta lingkunga disekitarnya 
Perkembangan sosial emosional anak pada usia 5-6 tahun, anak sudah mulai menyadari dirinya, kesadaran ini di peroleh dari pengalamannya yang mereka lalui, serta tidak setiap keinginannya sesuai dengan keinginan orang lain, sehinggga orang lain tidak selamanya memenuhi keinginannya. Bersamaan dengan itu, berkembang pula perasaan harga diri yang menuntut pengakuan dari lingkungannya. kemandirian merupakan karakteristik dari kepribadian yang sehat (healthy personality). Menurut Syamsu Yusuf (2008: 130) Kemandirian individu tercermin dalam cara berpikir dan bertindak, serta mampu mengambil keputusan, mengarahkan dan mengembangkan diri, serta menyesuaikan diri secara konstruktif dengan norma yang berlaku di lingkungannya.

Kemandirian selalu bergandeng dengan menumbuhkan tanggungjawab seorang anak. Tanggung jawab menurut kamus umum Bahasa Indonesia adalah menanggung segala sesuatunya atau memberikan jawab dan menanggung akibatnya. Menurut (Jacob Azerrad, 2005; 186) perilaku bertanggung jawab adalah perbuatan yang menunjukkan kemandirian. Dapat disimpulakan bahwa tanggung jawab adalah kesadaran manusia akan tingkah laku atau perbuatannya yang disengaja maupun yang tidak disengaja, Dalam meningkatkan tanggung jawab anak dilakukan dengan cara memberikan tugas dan memberikan kepercayaan pada anak bahwa anak bisa melakukannya. Dalam pembelajaran disekolah metode proyek sebagai salah satu cara pemberian pengalaman belajar kepada anak. Anak langsung dihadapkan pada persoalan sehari-hari yang menuntut anak untuk melakukan berbagai aktivitas sesuai dengan proyek yang dihadapinya. Berdasarkan dari aktivitas tersebut, anak memperoleh pengalaman yang akan membentuk sikap sebagai suatu kemampuan yang dimiliki. Setiap individu mempunyai tanggung jawab dari usia dini sampai dengan usia dewasa. Disetiap tingkatan usia memiliki tanggung jawab yang berbeda-beda. Tanggung jawab untuk anak usia dini lebih sederhana dibandingkan dengan tanggung jawab orang dewasa. Akan tetapi tanggung jawab tidak melihat batasan usia, setiap perbuatan yang dikerjakan pasti ada sesuatu yang harus dipertanggung jawabkan. Dari perbuatanperbuatan tersebut setiap orang harus bertanggung jawab kepada diri sendiri, keluarga, Tuhan, Negara dan masyarakat. Setiap perbuatan memiliki tanggung jawab yang berbeda-beda pula, akan tetapi setiap orang wajib bertanggung jawab akan setiap perbuatannya.

\section{Perilaku home service orang tua}

Anak merupakan individu yang unik dimana masing-masing memiliki bawaan, minat, kemampuan, dan latar belakang kehidupan yang berbeda-beda. Menurut Bredekamp (1987) anak juga memiliki keunikan tersendiri walaupun terdapat pola perkembangan anak yang dapat diprediksi, namun pola perkembangan anak memiliki perbedaan satu sama lain. John Locke mengemukakan, posisi pertama didalam mendidik seorang individu terletak pada keluarga. Melalui konsep tabula rasa John Locke menjelaskan bahwa individu adalah ibarat sebuat kertas yang saat lahir berwarna putih bersih, namun corak dan bentuk nya tergantung kepada orang tua bagaimana mengisi kertas kosong tersebut mulai anak tersebut bayi. Melalui pengasuhan, perawatan dan pengawasan yang terus menerus, diri serta kepribadian anak akan terbentuk.

"HOME SERVICE" dapat di artikan layanan rumah, tidak ada yang salah dalam pengertian kalimat tersebut. Home Service dapat di kaitkan dengan pembentukan karakter anak. Karakter adalah tabiat atau kebiasaan untuk melakukan sesuatu. Selama masa kecil selalu mendapatkan pelayanan prima dari orang tua atau orang bertugas membantunya. Untuk kalangan kaya raya mulai dari lahir mereka sudah diurus oleh 
pembantu atau Asisten Rumah Tangga (ART), Kemana-mana anak diikuti oleh baby sitter seluruh kegiatan bertumpu pada asisten rumah tangga. Bahkan sampai umur 9 tahun saja ada Baby sitter yang masih mengurus keperluan si anak karena orang tuanya sibuk bekerja dan tidak memberikan kebebasan orang yang mengurus anak tersebut memberikan pendidikan kepada anak nya. Satu contoh kecil, membuka bungkus permen yang akan dimakan anak. Karena terbiasa ada baby sitter atau ART, anak sampai besar memiliki prilaku dengan mudahnya menyuruh mereka membukakan bungkusnya kepada orang lain . Tidak mau bersusah payah berusaha lebih dulu atau mencari gunting misalnya.Sedang untuk keluarga di bawah perekonomian standart, berfikir dari pada merepotkan akhirnya ibu atau ayah nya yang mengerjakan. Adakala anak di ajak untuk mencari nafkah sedang unutuk pengembangan kepribadiannya mereka tidak di acuhkan. Ini lah paradigma yang ada. Menurut Kertajaya, 2010 Karakter adalah ciri khas yang dimiliki oleh suatu benda atau individu. Ciri khas tersebut adalah asli dan mengakar pada kepribadian benda atau individu tersebut, serta merupakan "mesin" yang mendorong bagaimana seorang bertindak, bersikap, berucap, dan merespon sesuatu

Menurut pendapat Euis( 2004:18 ) layanan orang tua di rumah merupakan rangkaian interaksi yang dilakukan setiap saat supaya anak memiliki kecakapan hidup. Home service yang di berikan orang tua seyogyanya membuat anak bisa berkembang sesuai dengan perkembangannya, Anak dibiarkan untuk mencari solusinya sendiri tanpa harus orang dewasa atau orang tua menghawatirkan kemampuannya. Contoh lain yaitu memakai kaus kaki dan sepatu. Karena tak sabar melihat si anak mencoba memakai sepatunya sendiri maka orang dewasa yang di sekitarnya terburu-buru memakaikan kepada anak. Saat anak sudah bisa makan sendiri, orang tua juga seringkali masih menyuapi makan karena berpikir jika tidak disuapi makannya akan lama dan malah tidak dimakan. Padahal jika anak dibiarkan tidak makan, maka anak tidak akan pernah merasa apa namanya lapar. Dan saat lapar datang seorang anak secara otomatis akan memasukkan makanan ke dalam mulutnya. Bagaimana dia akan belajar makan sendiri jika dia tidak pernah merasakan apa itu namanya lapar? Bagaimana dia akan belajar membuat minuman sendiri jika dengan hanya memanggil ART atau baby sitter atau orang tuanya saja minuman itu akan datang sendiri kepadanya. Pendapat shapiro(1992:27) bahwa orang tua yang memiliki prilaku home service yang berlebihan terhadap anak berusa menjalankan rumah tangganya yang didasari pada struktur dan tradisi, sehingga banyak hal menjadi tekanan pada mereka akan keteraturan dan pengawasan yang membebani anak. Berdasarkan pendapat diatas bahwa home service yang di berikan orang tua terhadap anak menghasilkan berbagai macam bentuk prilaku moral anak. Oleh karena itu orang tua harusnya bisa memahami dan mengetahui bagaimana mengelola home service yang baik. Menurut Armijn Chandra Santota Besman, S. IP, S. Psi, Psikolog ( pontianak post januari 2017) mengatakan terlalu berlebihan dalam menerapkan Home service kepada anak bukanlah cara yang tepat. "Jika layanan tersebut terlalu berlebihan, akibat negatifnya jauh lebih banyak ketimbang dampak positif," Dalam hal mengobati prilaku anak sangat sulit untuk bisa secepat itu di atasi serta melalui proses dan stimulus yang panjang.

\section{METODOLOGI PENELITIAN}

Penelitian ini termasuk penelitian lapangan (Field Research). Penelitian lapangan adalah penelitian yang dilakukan di suatu tempat atau lokasi yang dipilih untuk meneliti atau menyelidiki sesuatu yang terjadi di tempat tersebut. Metode yang digunakan adalah berbasis masalah ( problem based). Menurut sanjaya (2013 - 2014) Rangkaian aktifitas penelitian yang menekankan kepada proses penyelesaian masalah yang dihadapi secara ilmiah dan berdasarkan pengalaman langsung pada suatu masalah. 
Pendekatan penelitian ini menggunakan pendekatan kualitatif dengan jenis penelitian deskriptif yaitu dengan menyajikan analisis mengenai keadaan secara rinci dan akurat melalui hasil data deskriptif yang berasal dari data tertulis dan wawancara lisan dari orang-orang terkait.. ( Abdurrahman Fathoni, Metodologi penelitian dan Teknik penyusunan laporan penelitian(Jakarta: PT. Rineka Cipta, 2006)

Populasi penelitian ini adalah para orangtua dan siswa di TK Insan Cendekia yang berada di daerah tulangan sidoarjo yang berusia 5 - 6 tahun. Sampel penelitian dilakukan dengan purposive random sampling yang representatif terhadap populasi penellitian. Waktu penelitian adalah tahun ajaran 2018/2019. Karakteristik subjek penelitian adalah: (1) orangtua yang memiliki anak usia 5 - 6 tahun, (2) pendidikan orang tua minimal lulus SD, (4) mampu berkomunikasi dengan baik secara lisan dan tulisan. Penelitian ini menggunakan instrumen berupa kuesioner tentang keterlibatan orangtua yang dilihat dari tiga hal: data demografis (pendidikan dan pekerjaan orangtua), keterlibatan orangtua di TK, dan keterlibatan orangtua di rumah. Kisi-kisi instrumen disusun dengan mengacu pada dua bentuk keterlibatan menurut Jeynes (di rumah dan di sekolah), yang dipadukan dengan empat tipe dari model Epstein yaitu: tipe komunikasi dan tipe relawan untuk keterlibatan di TK, serta tipe tugas keorangtuaan dan tipe komunikasi untuk keterlibatan orangtua di rumah. Instrumen telah diuji validitas dan reliabilitasnya.. Data yang diperoleh di lapangan disajikan secara deskkriptif analisis kualitatif. Instrumen penelitian mengacu kepada standart tingkat pencapaian anak berdasarkan permen diknas 58 indikator sosial emosional anak.

Tabel 3.1 Instrumen wawancara pengembangan kemandirian anak usia 5-6 tahun berdasar peraturan pemerintah No. 58 Tahun 2009

Instrumen wawancara kemandirian anak 5-6 tahun

a. Apakah ananda dirumah punya inisiatif untuk melakukan aktifitas kebutuhannya sendiri?

b. Apakah aktifitas itu dibantu oleh orang tua?

c. Berapa besar aktifitas membantu orang tua terhadap kegiatan anak tersebut?

a. Apakah ananda suka menunjukkan kehebatannya di depan orang tua?

b. Kehebatan tersebut di tunjukkan di dasari pertanyaan orang tua atau spontan dari inisiatif anak?

c. Berapa besar kesadaran ananda menunjukkan percaya dirinya ?

a. Apakah Ananda suka datang terlambat kesekolah atau ketempat apapun yang memiliki jadwal?

b. Seberapa besar orang tua memberikan pemahaman tentang kedisiplinan kepada anak?

c. Apakah ananda memahami aturan main pada saat bermain?

d. Apakah ananda memiliki jadwal beraktifitas?

a. Apakah ananda menangis saat ia berada di posisi kalah atau tidak mendapat reward baik?

b. Apakah ananda selalu berusaha memberikan yang terbaik?

c. Berapa besar bantuan orang tua untuk anak menun jukkan keberhasilannya? 
Tabel 3.2 Instrumen wawancara pengembangan tanggung jawab anak usia 5-6 tahun berdasar peraturan pemerintah No. 58 Tahun 2009

\begin{tabular}{|l|}
\hline Instrumen wawancara tanggungjawab anak usia 5-6 tahun \\
\hline a. Apakah ananda pulang sekolah meletakkan seragamnya di tempat yang telah di \\
sediakan? \\
b. Berapa besar peran orang tua dalam aktifitas diatas? \\
c. Apakah ananda mengerti terhadap sampah? \\
d. Seberapa besar orang tua membantu penanganan kebersihan diri dan lingkungan \\
anak? \\
\hline a. Apakah ananda suka memberi apa yang dia punya? \\
b. Seberapa besar kesadaran orang tua terhadap keinginan anak \\
c. Bagaimana cara anak melihat temannya saat membutuhkan pertolongan? \\
d. Seberapa besar anak dapat membantu orang tua di rumah \\
\hline a. Apakah ananda suka merengek apa bila tidak bisa memakai baju \\
b. Apakah orang tua selalu merespon terhadap rengekan anak dalam memakaikan \\
atribut nya? \\
c.Bagaimana respon anak saat ia mau beraktiffitas? \\
d.Apakah anak akan berdiam diri apa bila ia tidak mendapat respon keinginan dari \\
lingkungannya? \\
e.Seberapa besar bantu an orang tua terhadap permintaan bantuan anak? \\
\hline a. Apakah ananda bangun tidur harus di bangunkan? \\
b. Apakah ananda mandi di mandikan? \\
c. Apakah orang tua ada saat ananda membutuhkan bantuan? \\
d. Apakah aktifitas sehari - hari ananda di bantu \\
e. Seberapa besar orang tua membantu dalam kesadaran mengatur diri sendiri anak \\
\hline
\end{tabular}

Tabel 3.3 Instrumen observasi pengembangan tanggung jawab dan kemandirian anak usia 5-6 tahun berdasar peraturan pemerintah No. 58 Tahun 2009

\begin{tabular}{|c|c|c|c|c|}
\hline Instrumen observasi & BB & MB & $\mathrm{BSH}$ & BSB \\
\hline $\begin{array}{l}\text { 1. Kemampuan anak mampu bertanggung jawab } \\
\text { menyelesaikan tugas sekolah di rumah } \\
\text { 2. Kemampuan anak akan merapikan barang yang } \\
\text { berserakan dilantai } \\
\text { 3. kemampuan anak sabar saat ia menunggu giliran } \\
\text { bermain dengan temannya. } \\
\text { 4. Kemampuan anak mau menunggu dengan sabar } \\
\text { saat ibu masih mengerja kan tugas yang lain } \\
\text { 5. Keberanian menunjukkan hasil karya atau } \\
\text { 6ekerjaan anak } \\
\text { 6emampuan tepatwaktu saat bermain dan } \\
\text { kehadiran dalam suatu kegiatan } \\
\text { 7. Kemampuan bertanya dan menjawab saat } \\
\text { 8. Peraktifitas } \\
\text { 9. Kemonanak yang selalu bertanya pada saat } \\
\text { demampuan menonjolkan kehebatannya }\end{array}$ & & & & \\
\hline
\end{tabular}




\begin{tabular}{|c|c|c|c|c|}
\hline Instrumen observasi & $\mathrm{BB}$ & MB & $\mathrm{BSH}$ & BSB \\
\hline $\begin{array}{l}\text { 10. Kemampuan bertanya apabila tdk dapat bintang } \\
4 \\
\text { 11. Kemampuan melepas dan memakai sepatu di } \\
\text { sekolah } \\
\text { 12. Kemampuan memuji teman } \\
\text { 13. Sikap anak apabila guru mengatakan hasil karya } \\
\text { temannya jauh lebih baik, apakah dia menangis } \\
\text { 14. Kemampuan mendengarkan instruksi orang lain } \\
\text { 15. Kemampuan saling membantu dan berkerja sama } \\
\text { 16. Kemampuan keiklaskan mengerjakan sesuatu } \\
\text { 17. Kemampuan peduli dengan lingkungan sekitar } \\
\text { baik tempat bermain maupun tempat belajar }\end{array}$ & & & & \\
\hline
\end{tabular}

\section{HASIL DAN PEMBAHASAN}

Penelitian ini di laksanakan di TK Insan Cendekia di daerah tulangan yang berdiri sejak tahun 2008. Penelitian ini menghasilkan data tentang data demografis orangtua (pekerjaan dan pendidikan) orangtua, keterlibatan orang tua di TK, dan keterlibatan orangtua dalam pengasuhan anak di rumah. Terlihat bahwa hampir semua ayah bekerja dengan persentase di atas $95 \%$, sedangkan ibu yang bekerja hampir $70 \%$. Artinya jumlah ibu yang tidak bekerja dengan waktu cukup banyak sebesar 30\% sehingga dapat diasumsikan bahwa ibu yang tidak bekerja ini memiliki kesempatan yang lebih besar untuk mengantar jemput anaknya ke TK daripada ibu yang bekerja. Berdasarkan yang ada terlihat bahwa pekerjaan ayah dan ibu didominasi sebagai pegawai swasta. Bagi ibu yang berkerja, siswa biasa di asuh oleh asisten rumah tangga dan pihak keluarga dekat seperti nenek/kakek atau tante

Dari 70\% ibu yang bekerja, 50\% anak di asuh oleh asisten rumah tangga dan $20 \%$ di asuh Oleh keluarga terdekat. Jumlah siswa TK Insan cendekia berjumlah 60 siswa dengan komposisi 35 siswa perempuan dan 25 siswa laki-laki.

Setiap orangtua pasti ingin memberikan perlindungan kepada anaknya. Apalagi saat ini tindak kejahatan dan tantangan hidup yang dihadapi sangat lah komplek. Sehingga sering sekali orangtua terus menurus mengawasi gerak-gerik anak secara berlebihan. Bahkan, mereka terus mengikuti dan mengkhawatirkan kondisi anak secara berlebihan, tergambar dari hasil penelitian di bawah ini perilaku home service anak tergambar pada aktifitas sekolah.

Tabel 4.1 hasil Oservasi Instrumen pengembangan tanggung jawab dan kemandiriran anak usia 5-6 tahun berdasar peraturan pemerintah No. 58 Tahun 2009

\begin{tabular}{|c|c|c|c|c|}
\hline Instrumen observasi & $\mathrm{BB}$ & MB & BSH & BSB \\
\hline $\begin{array}{l}\text { 1. Kemampuan anak mampu bertanggung } \\
\text { jawab menyelesaikan tugas sekolah di } \\
\text { rumah } \\
\text { 2. Kemampuan anak akan merapikan barang } \\
\text { 3. yg berserakan dilantai } \\
\text { kemampuan anak sabar saat ia menunggu } \\
\text { giliran bermain dengan temannya. }\end{array}$ & & $\begin{array}{l}15 \% \\
5 \% \\
15 \%\end{array}$ & $\begin{array}{l}40 \% \\
60 \% \\
40 \%\end{array}$ & $\begin{array}{l}45 \% \\
35 \% \\
45 \%\end{array}$ \\
\hline
\end{tabular}




\begin{tabular}{|c|c|c|c|c|c|}
\hline \multicolumn{2}{|r|}{ Instrumen observasi } & $\mathrm{BB}$ & MB & $\mathrm{BSH}$ & BSB \\
\hline & $\begin{array}{l}\text { Kemampuan anak mau menunggu dengan } \\
\text { sabar saat ibu masih mengerja kan tugas } \\
\text { yang lain }\end{array}$ & & $20 \%$ & $30 \%$ & $50 \%$ \\
\hline & $\begin{array}{l}\text { Keberanian menunjukkan hasil karya atau } \\
\text { pekerjaan anak }\end{array}$ & & $15 \%$ & $45 \%$ & $40 \%$ \\
\hline 6. & $\begin{array}{l}\text { Kemampuan tepatwaktu saat bermain dan } \\
\text { kehadiran dalam suatu kegiatan }\end{array}$ & & $10 \%$ & $55 \%$ & $35 \%$ \\
\hline & $\begin{array}{l}\text { Kemampuan bertanya dan menjawab saat } \\
\text { beraktifitas }\end{array}$ & & $25 \%$ & $40 \%$ & $35 \%$ \\
\hline 8. & $\begin{array}{l}\text { Perilaku anak yang selalu bertanya pada saat } \\
\text { demonstrasi }\end{array}$ & & $25 \%$ & $45 \%$ & $30 \%$ \\
\hline 9. & Kemampuan menonjolkan kehebatannya & & $15 \%$ & $35 \%$ & $50 \%$ \\
\hline & $\begin{array}{l}\text { Kemampuan bertanya apabila tdk dapat } \\
\text { bintang } 4\end{array}$ & & $35 \%$ & $30 \%$ & $35 \%$ \\
\hline & $\begin{array}{l}\text { Kemampuan melepas dan memakai sepatu } \\
\text { di sekolah }\end{array}$ & & $15 \%$ & $30 \%$ & $55 \%$ \\
\hline 12. & Sikap memuji teman & & $30 \%$ & $40 \%$ & $30 \%$ \\
\hline & $\begin{array}{l}\text { Sikap anak apabila guru mengatakan hasil } \\
\text { karya temannya jauh lebih baik, apakah dia } \\
\text { menangis }\end{array}$ & & $5 \%$ & $25 \%$ & $70 \%$ \\
\hline & $\begin{array}{l}\text { Kemampuan mendengarkan instruksi orang } \\
\text { lain }\end{array}$ & & $10 \%$ & $30 \%$ & $60 \%$ \\
\hline & $\begin{array}{l}\text { Kemampuan saling membantu dan berkerja } \\
\text { sama }\end{array}$ & & $30 \%$ & $35 \%$ & $35 \%$ \\
\hline & $\begin{array}{l}\text { Kemampuan keiklaskan mengerjakan } \\
\text { sesuatu }\end{array}$ & & $55 \%$ & $25 \%$ & $20 \%$ \\
\hline & $\begin{array}{l}\text { Kemampuan peduli dengan lingkungan } \\
\text { sekitar baik tempat bermain maupun tempat } \\
\text { belajar }\end{array}$ & & $30 \%$ & $35 \%$ & $35 \%$ \\
\hline
\end{tabular}

Hasil penelitian secara observasi, Berdasarkan data tabel di atas terlihat bahwa aspek kesadaran diri anak pada point 1 sampai 9 terlihat bahwa perkembangannya sesuai dengan harapan stimulus yang di dapat anak di rumah dan di sekolah dapat tercermin dalam kegiatan anak sehari-hari, Sedang hasil observasi pada aspek tanggungjawab anak pada point 13 sampai 20 terlihat bahwa perkembangan nya sesuai dengan harapan namun prosentase anak yang masih berkembang terlihat cukup tinggi di banding pada aspek kesadaran diri di angka 10\%-20\%. Anak tidak mengalami tantangan yang berarti, Mosston dan Asworth (dalam Yudha M. Saputra dan Rudyanto (2005: 33)) menjelaskan bahwa memecahkan masalah adalah ketika seorang anak merencanakan, memprediksi, mengambil keputusan, mengobservasi hasil dariaksinya, kemudian membuat kesimpulan, sementara seorang guru bertindak sebagai fasilitator. Dengan demikian, anak dapat mengkonstruksi pengetahuannya sendiri melalui pengalaman langsungnya. Selain itu juga dapat mendorong anak untuk berpikir kritis. Berdasarkan pendapat ahli di atas pengkontruksian pengetahuan anak dan mengajak anak untuk berpikir kritis ( kesadaran diri dan bertanggungjawab) terjadi apabila anak di hadap kan oleh sebuah permasalahan yang mana permasalan tersebut bisa ia selesaikan sendiri tanpa harus di bayang-bayangi oleh kontruksi pola pikir orang tua 
Hasil penelitian berbasis wawancara tergambar sebagai berikut: Pada pertanyaan aspek menjaga diri sendiri dari lingkungannya: berdasarta hasil wawancara $65 \%$ dari jumlah siswa masih di bantu oleh orang tua sedang 35\% dari jumlah siswa sudah punya kesadaran sendiri untuk menjaga diri dan lingkungannya. Pada pertanyaan aspek mau berbagi, menolong dan membantu teman hasil wawancara tergambar $70 \%$ dari jumlah siswa aspek tersebut masih belum terbentuk sedang 30\% dari jumlah siswa aspek tersebut sdh terbentuk. Pada pertanyaan aspek mengendalikan perasaan anak terhadap orang tua hampir sebagian besar $80 \%$ orang tua segera memberikan respon terdapat anak, $20 \%$ orang tua memberikan respon memberikan arahan untuk bertanggungjawab terhadap yg ia lakukan. Pada pertanyaan aspek mengatur diri sendiri $90 \%$ anak masih aktifitas dirumah bergantung dengan orang tua atau asisten rumah tangga di karenkan alasan orang tua kasihan dan merasa bahwa anak nya masih kecil, 10\% mengajari anak untuk melakukan kewajibannya dengan sendiri. Pada pertanyaan aspek menunujukkan sikap mandiri dalam memilih kegiatan $60 \%$ orang tua mengarahkan anak melakukan kegiatan berdasarkan keinginan orang tua di karena tidak percaya diri, rasa khawatir dan takut akan terjadi sesuatu dengan anak tersebut. Sedang $40 \%$ anak orang tua membiarkan anak memilih kegiatan sesuai dengan keinginannya. Pada pertanyaan aspek menunjukkan rasa percaya diri di karenakan lingkungan orang tua di lembaga insan cendekia rata-rata memiliki pengetahuan dan pendidikan sarjana maka hampir $75 \%$ orang tua mempunyai peran mengembangkan rasa percaya anak walau pun sebagian kecil masih ada yang mendampingi, sedang 25\% anak di usia 5-6 tahun orang tua nya masih belum percaya dengan kemampuan anak nya sehingga pengembangan diri anak kurang teraplikasikan dengan beberapa alasan orang tua yang sibuk dan tidak menyadari bahwa potensi anak yang harus dikembangkan. Pada pertanyaan aspek memahami peraturan dan disiplin tergambar $60 \%$ memiliki kesadaran untuk disiplin dan komitmen, Terlihat orang tua memberikan contoh untuk mengajak anak-anak tidak terlambat pada saat berangkat kesekolah dan mengajarkan anak untuk terbiasa tidur siang, sedang $40 \%$ masih didominasi oleh keadaaan yang kadang-kadang terlambat dan kadang-kadang habis main tidak membereskan mainan. Hal ini bisa tergambar anak yang dibiarkan semaunya sendiri. Pada pertanyaan aspek memiliki sikap gigih (tidak mudah menyerah) prilaku orang tua mensuport anak sebayak 80\%anak mendapatkan support yang tinggi untuk berjuang dan meraih sesuatu dengan baik, sedang $20 \%$ anak, orang tua nya membiarkan anak beraktifitas sesuai dengan kemampuannya yang ada saat ini.

"HOME SERVICE" dapat di artikan layanan rumah, tidak ada yang salah dalam pengertian kalimat tersebut. Home Service dapat di kaitkan dengan pembentukan karakter anak. Karakter adalah tabiat atau kebiasaan untuk melakukan sesuatu. Pada penelitian ini bisa kita analisis bahwa orang tua atau orang dewasa yang selalu memberikan pelayanan home service anak tidak sesuai dengan perkembangannya maka terlihat betul pada aktifitas anak di sekolah. Para oramg tua atau orang dewasa lihatlah sosok anak itu sesuai dengan fitrahnya, umurnya semakin bertambah, perkembangan nya semakin meningkat dan kecerdasannya juga semakin baik. Hargai proses berjalannya waktu supaya terbentuk karakter yang baik pada diri anak.

\section{KESIMPULAN}

Keberhasilan pencapaian tugas perkembangan dapat secara tidak langsung tergambarkan pada perilaku anak. Perilaku dalam keseharian anak yang dapat diamati, secara tidak langsung akan mencerminkan bagaimana pembentukan perilaku eksternalnya dalam upaya mencapai tugas perkembangannya. Tumbuh kembang pada anak usia dini sangatlah pesat, maka dari itu pada usia ini anak perlu distimulasi untuk 
meningkatkan potensi-potensi yang dimiliki anak, selain itu sikap-sikap positif pada usia dini juga perlu dikembangkan sehingga anak mampu menyesuaikan diri dan berperilaku sesuai aturan yang ada, serta keberadaan anak dapat diterima di lingkungannya. Salah satu sikap yang perlu dikembangkan pada usia dini adalah sikap tanggung jawab atas apa yang akan dilakukan dan tanggung jawab atas apa yang telah diberikan oleh orang lain untuk dirinya. Pentingnya sikap tanggung jawab untuk anak usia dini adalah sebagai dasar atau pondasi untuk kehidupan selanjutnya. Perkembangan anak yang berhasil sesuai dengan tahapannya didukung oleh beberapa faktor, baik internal dan eksternal. Dukungan eksternal dapat berasal dari keluarga dan lingkungannya, diantaranya adalah pola asuh, pola hubungan keluarga, peran dan fungsi keluarga., dukungan lingkungan rumah dan sekolah dan beberapa faktor pendukung lainnya. layanan orang tua di rumah merupakan rangkaian interaksi yang dilakukan setiap saat supaya anak memiliki kecakapan hidup. Home service yang di berikan orang dewasa/orang tua kepada anak memang lah perlu tapi kita sebagai orang dewasa/orang tua berikan lah home service sesuai dengan perkembangannya supaya anak akan hidup dan berkembang dengan baik dan tidak akan meninggal kan sebuah goresan pada saat ia dewasa nanti.

\section{DAFTAR PUSTAKA}

Abdurrahman Fathoni, Metodologi penelitian dan Teknik penyusunan laporan penelitian (Jakarta: PT. Rineka Cipta, 2006)

Anita Lie \& Sarah Prasasti. (2004). 101 Cara Membina Kemandirian dan Tanggung Jawab Anak (usia balita sampai pra remaja). Jakarta: PT Elex Media Komputido.

Brewer.jo Ann. 2007. Early Childhood Education. USA: Perason Graha, C. (2007).

Keberhasilan anak di tangan orangtua. Jakarta: Elex Media Komputindo

Hurlock Elizabeth B (1992),Psikologi perkembangan anak Jilid 1-2. Jakarta: Penerbit Erlangga

Indrijati, Herdina. (2017), Psikologi perkembangan dan pendidikan anak usia dini. Jakarta: Kencana Prenata Media Group

Lickona, T. 2012. Educating For Character, : How Our Schools Can Teach Respect and Responsibility, Terjm. Juma Abdu Wamaungo, Mendidik Untuk Membentuk Karakter Jakarta: PT. Remaja Rosdakarya.

Permendikbud Nomor 137 Tahun 2013 Tentang Standart Nasional Pendidikan AUD

Permendikbud Nomor 146 Tahun 2014 tentang kurikulum 2013 Pendidikan Anak Usia

Dini Peraturan pemerintah No. 58 Tahun 2009 tentang Standart Tingkat

Pencapaian perkembangan anak

Rosmala Dewi. (2005). Berbagai Masalah Anak Taman Kanak-Kanak. Jakarta:

Departemen Pendidikan Nasional Direktorat Jenderal Pendidikan Tinggi Direktorat

Pembinaan Pendidikan Tenaga Kependidikan dan Ketenagaan Perguruan Tinggi

https://www.pontianakpost.co.id/sikap-berlebihan-pada-anak" marsita Riandi” 